Biografistyka Pedagogiczna

Rok 1 (2016) nr 1

ISSN 2543-6112; e-ISSN 2543-7399

DOI: $10.36578 /$ BP.2016.01.11

Ryszard Skrzyniarz*

\title{
„Czas i odległość, jakie znamy nie istnieją" - doświadczenia śmierci w biografii
}

\author{
'The Time and Distance That We Know Do Not Exist': Death \\ Experience in a Biography
}

\begin{abstract}
The article shows and analyses an interviewee's experiences from the border of life and death. He claims that he had many of them in his life. This paper discusses only ten of them, which occurred over thirty years of his life: 1) darkness and light; 2) out-of-body experience and walk; 3) balls of fire and planets; 4) the view from space; 5) the fight against Satan; 6) encompassing darkness and fear; 7) a gap and a high tide; 8) drowning; 9) garden, flowers in the meadow; 10) the heavenly Jerusalem. All of these experiences were also related to his attitudes, way of life, faith in God and its negation.

The accounts also include educational values, showing the relationship of human life with two essential elements of this experience: love for people and knowledge gained. After these experiences from the border of life and death, the interviewee realized that: 1) life does not end with death; 2) God exists and is a merciful Father; 3) it is most important to love and respect all forms of life.
\end{abstract}

Keywords: biography, narrative interview, a chronic disease, death experience

Od zawsze człowiek interesował się tym, co się z nim stanie po śmierci, i choć prawie wszystkie religie świata zapewniają, że ziemskie życie nie kończy się wraz ze śmiercią, to chęć poznania tego, czy istnieje jakiś „tamten świat”, budzi ciekawość, mobilizuje

* Ryszard Skrzyniarz - dr hab., profesor Katolickiego Uniwersytetu Lubelskiego Jana Pawła II w Lublinie, kierownik Katedry Biografistyki Pedagogicznej, skrzyniarz@kul.pl. 
do badań i stawiania wielu pytań o przyszłość po śmierci, o to, co nastąpi po niej. Czy życie kończy się wraz z nią, czy jednak trwa dalej? Czy śmierć oznacza koniec, czy jest początkiem czegoś innego? Jeżeli jest początkiem nowego życia, to jak ono wygląda, co się dzieje z człowiekiem, z jego duszą, dokąd trafia? Wiele podobnych pytań odwiecznie nurtuje człowieka.

Celem publikacji będzie ukazanie i analiza przeżyć mojego bohatera, związanych z jego postawami, sposobem życia, wiarą w Boga i jej negacją. Jego relacje zawierają również wartości pedagogiczne, ukazujące związek życia ludzkiego z dwoma istotnymi elementami tego doświadczenia, w którym są miłość i wiedza.

Już człowiek pierwotny potrafił odróżnić dobro od zła, niebo od piekła i wierzył w życie po śmierci. Prehistoryczne malunki naskalne są tego dowodem. W eposie o Gilgameszu (przekaz sprzed 2500 lat przed Chrystusem) bohater po śmierci przyjaciela Enkidu pokonuje ciemny tunel, na którego końcu rozbłyskuje światło, oślepiony tym światłem nie chce wracać na ziemię. W starożytnym Egipcie w Egipskiej Księdze Umartych zostały zawarte opisy porzucania ciała ziemskiego przez duszę i przekraczania progu innego świata, w którym dostrzega ona światło, następnie znajduje ukojenie, robi przegląd życia, aby po oczyszczeniu stopić się z Ra (stwórczą zasadą uniwersum). W starożytnej Persji istniało przekonanie o istnieniu innego świata, w którym dusza trafia na swoją świadomość, ważone są jej czyny, a następnie trafia do wiecznego raju lub ciemnych lochów piekieł. W antyku zarówno Grecy (Homer, Odyseja ${ }^{1}$, Platon, Państwo), jak i Rzymianie (Wergiliusz, Eneida ${ }^{2}$ ) poruszali problem śmierci i życia po niej. W religiach Wschodu - hinduizmie i buddyzmie - dusze oczekiwały na reinkarnację, a jedynie nieliczne wiązały się z boskim praźródłem. W religiach monoteistycznych (judaizm, chrześcijaństwo, islam) człowiek żyje tylko raz, a jego nieśmiertelna dusza osiąga zbawienie lub zostaje potępiona ${ }^{3}$.

W 1965 r. Elisabeth Kübler-Ross - pionierka w badaniach nad śmiercią i umieraniem - napisała książkę Rozmowy o śmierci i umieraniu ${ }^{4}$. Starała się przez nią zrozumieć psychiczne i społeczno-moralne problemy umierających. Amerykański psycholog

1 Homer, Odyseja, tłum. L. Siemieński, Warszawa 2000, s. 60, 162.

2 Wergiliusz, Eneida. Epopeja w dwunastu księgach, tłum. i oprac. I. Wieniewski, Kraków 1978, S. 155 .

3 B. Jakoby, Drogi nieśmiertelności. Nowa wiedza o doświadczeniach z pogranicza życia i śmierci, przeł. T. A. Czarnawski, Warszawa 2012, s. 32-70.

4 E. Kübler-Ross, Koło życia. Rozważania o życiu i umieraniu, tłum. J. Korpanty, Warszawa 2010. 
i lekarz Raymond A. Moody ${ }^{5}$ w książce Życie po życiu ${ }^{6}$, wydanej w 1975 r., zapoczątkował badania narracji osób (zgromadził ponad sto historii), które doświadczyły śmierci klinicznej, a potem zostały przywrócone do życia. Niezwykłe relacje tych osób są świadectwem istnienia życia po śmierci fizycznej. Te badania - dzieci i osób dorosłych - kontynuowali inni badacze, zwłaszcza lekarze i psychiatrzy. Posługiwali się oni najnowszymi technikami badawczymi i najróżniejszymi przyrządami, doszli do takich samych wniosków jak Moody ${ }^{7}$. Obecnie badacze renomowanych klinik i uniwersytetów publikują swoje badania w książkach i czasopismach. O życiu po śmierci powstało wiele książek, w których zostały opisane doświadczenia osób będących po drugiej stronie życia. Przedstawiciele różnych dziedzin nauki zajmują się badaniami tego typu zjawisk ${ }^{8}$.

Pragnę przedstawić historię osoby, która kilkanaście razy znalazła się na granicy życia i śmierci. Było to spowodowane tym, że ma ona zdiagnozowaną niewydolność węzła zatokowego, objawiającą się zatrzymaniami akcji serca na kilka, a niekiedy kilkanaście sekund. U mojego badanego serce stawało przede wszystkim w nocy, w początkowej fazie przerwy trwały do 3, a później nawet do 6 sekund. Jest to udokumentowane kilkakrotnymi badaniami holterem?

Mój bohater - Adrian ${ }^{10}$, to mężczyzna, jest w wieku 52 lat, z wyższym wykształceniem, mieszkający w Lublinie. Jest żonaty, ma dwóch studiujących synów i córkę, uczącą się w liceum. Pracuje w jednej z lubelskich szkół średnich. Zgodził się

5 Raymond Moody (ur. 30 czerwca 1944 w Porterdale, Georgia, USA) - znany jako autor książek dotyczących opisu doświadczeń z pogranicza śmierci klinicznej (NDE - near-death experiences), jego najlepiej sprzedającą się książką jest Życie po życiu.

6 R. A. Moody, Życie po życiu, przeł. I. Doleżal-Nowicka, Warszawa 1979, 2008.

7 Tamże, Wstęp do nowego wydania, Warszawa 2008, s. 9-18.

8 To tylko niewielki wybór szerokiej gamy publikacji dotyczących umierania i życia po życiu w doświadczeniach ludzi, którzy to przeżyli: M. T. Browne, Życie po śmierci, przeł. M. Kowalska, Warszawa 1997; R. Stone, Życie po śmierci, przeł. M. Korusiewicz, Katowice 1999; I. Wilson, Życie po śmierci, przeł. M. Glińska, Warszawa 1998; J. Long, P. Perry, Evidence of the Afterlife. The Science of Near-Death Experiences, New York 210; M. H. Brown, Po drugiej stronie, przeł. M. H. Kotlarz, Gdańsk 2010, wyd. 2: przeł. M. Szerocki, Kraków 2013; na polskim gruncie: M. Rymuszko, Polskie $\dot{z}$ ycie po życiu. Relacje ludzi uratowanych ze stanu śmierci klinicznej, Warszawa 2004.

9 Holter EKG - urządzenie rejestrujące pracę serca (EKG), przez 24 godziny na dobę w celu szczegółowej analizy pracy serca. Wynalazcą holtera był amerykański biofizyk Norman Holter (1914-1983).

10 Badany nie życzył sobie ujawnienia swojego prawdziwego imienia. Zaproponował fikcyjne imię Adrian, którego będę używał w artykule. 
opowiedzieć swoje przeżycia z pogranicza życia i śmierci, które miał z różnym natężeniem na przestrzeni lat 1984-2015. Początkowo nie przywiązywał do nich większej wagi, później zaczął je spisywać w prowadzonym notatniku, przy nielicznych - tych najbardziej wyrazistych - notował nawet daty dzienne.

W swoim życiu doświadczył on wiele różnych przypadków, w których znalazł się na krawędzi życia i śmierci. Są one charakterystyczne i związane z trybem życia, wyznawanymi wartościami, podejściem do wiary i Boga. Z jego różnych doświadczeń wybrałem dziesięć najbardziej charakterystycznych zdarzeń z różnych okresów jego życia.

\section{Ciemność i światło}

W wieku dwudziestu lat przeżył dwa doświadczenia. Pierwsze z nich miał w lutym 1984 r. Nocą położył się do łóżka spać i w pewnej chwili ogarnęła go niesamowita ciemność: „ciemność, jakiej nigdy nie widziałem. Byłem przerażony, bardzo się bałem, czułem przerażającą pustkę i nicość. Nic nie widziałem, a czułem jedynie apokaliptyczny strach i lęk. W pewnym momencie się obudziłem i zobaczyłem zarys okna i mebli w moim pokoju". Drugie doświadczenie miał w maju tego samego roku. Był już po maturalnym egzaminie pisemnym z języka polskiego, a przed egzaminem pisemnym z matematyki.

\footnotetext{
„Obudziłem się rano, a mój pokój był skąpany w porannym słońcu. Leżałem w łóżku i na myśl o egzaminie pisemnym z matematyki byłem przerażony. W jednym momencie zostałem otoczony niesamowicie jasnym światłem, było ono bardzo intensywne i ciepłe. Czułem się w nim bardzo dobrze, a przede wszystkim bezpiecznie. Zapomniałem o maturze, nic mnie nie interesowało. W pewnym momencie ocknąłem się, znalazłem się w rzeczywistości, a tamtego światła już nie było. Bardzo chciałem powrócić do tego, co mnie spotkało".
}

Bohater twierdzi, że: „Te dwa wydarzenia wiążę z czasem moich wyborów życiowych i egzaminu maturalnego, kiedy to decydowały się losy mojego przyszłego życia". Twierdził on, że „ta ciemność to było zło, a ciepłe światło i jasność to było dobro, bezgraniczne i bezwarunkowe dobro, jakie mnie otoczyło".

\section{Wyjście z ciała i spacer}

Zdarzyło się to wiosną 1985 r. lub 1986 r. Bohater był po przeziębieniu, które skutkowało długotrwałym okresem leczenia i pobytu w łóżku w warunkach domowych. 
To była noc. W pewnym momencie zacząłem wstawać i poczułem, jakbym się odrywał od mojego ciała. Coś jak rozpinanie rzep. Widziałem, jak moje ciało pozostaje w łóżku, a ja przechodzę przez zamknięte drzwi, idę korytarzem, wspinam się po schodach i wchodzę do pokoju Darka, mojego brata. Widziałem, jak śpi w swoim łóżku, nie chciałem go budzić, więc wyszedłem, znów nie otwierając drzwi, zszedłem na dół tą samą drogą, którą przyszedłem, dotarłem do mojego pokoju, w którym leżało moje ciało - widziałem je. Usiadłem na łóżku i zacząłem w nie wchodzić. Najpierw dopasowałem się od nóg, a później resztą ciała. Zaraz się przebudziłem. Pamiętam, że rano poczułem się dobrze, a następnego dnia byłem już całkiem zdrowy.

W tym przypadku mój bohater wiąże te przeżycia z chorobą i tragicznymi przeżyciami, jakie go spotkały. „Kierunek studiów, który wybrałem, nie satysfakcjonował mnie. Czułem się źle. Nie akceptowałem tego, co działo się wokół mnie. Kolega popełnił samobójstwo. Ogólnie byłem rozbity i nie wiedziałem, co mam dalej robić w swoim życiu".

\section{Kule ognia i planety}

Było to na początku lat dziewięćdziesiątych, gdy przeżył następujące wydarzenie. Podczas snu Adrian w pewnej chwili znalazł się na ulicy miasta, niebo było bardzo pogodne, gdy z niego zaczęły spadać kule ognia, które niszczyły wokół niego wszystko, jemu samemu nie czyniąc krzywdy. Słyszał świst spadających kul ognia i grzmot uderzeń o ziemię. Zbudził się przerażony tym przeżyciem.

Inne wydarzenie też miało miejsce podczas snu, gdy znalazł się na dużej płaskiej przestrzeni, była noc, a na niebie znajdowało się kilkanaście planet różnej wielkości. Wszystkie one świeciły białym światłem, jak księżyc w pełni, ale światło to było zwielokrotnione, nieoślepiające, bardzo ciepłe i przyjazne. Czuł jakby był w jakiś nieznanym układzie planetarnym.

\section{Widok z kosmosu}

Mój bohater nie pamięta dokładnej daty, ale wydarzyło się to gdzieś około $1998 \mathrm{r}$. Podobne doświadczenia miał jednak wielokrotnie w swoim życiu. To mu utkwiło w pamięci, bo było nieco inne od pozostałych.

Zacząłem unosić się nad Ziemią, tak że najpierw widziałem domy, drzewa, rzeki, jeziora, następnie coraz szybciej oddalałem się, Ziemia stała się niebiesko-biało- 
-zieloną kulą, jaką można zobaczyć na fotografiach ze stacji kosmicznych. Odlatywałem do tyłu, cały czas mając przed oczami Ziemię. Byłem tam sam, bez żadnego skafandra, statku kosmicznego, a jednak się nie bałem. Minąłem Księżyc i następne planety Układu Słonecznego, mijałem gwiazdy i z coraz większą prędkością zmierzałem do centrum Drogi Mlecznej, która była coraz bardziej jasna i świeciła ciepłym białym światłem. Kiedy już mi się wydawało, że wpadnę w środek tego pulsującego i jasnego, ale nieoślepiającego światła, wówczas obudziłem się.

W innych tego typu wizjach czy stanach znajdował się wysoko nad Ziemią, w kosmosie, ale nie docierał do krańca Układu Słonecznego. Bohater lubi te sny, ponieważ widok Ziemi z kosmosu jest dla niego zawsze ekscytującym przeżyciem, a Ziemia zawsze ma cudowne nieziemskie kolory.

\section{Walka z szatanem}

W październiku 2000 r. mój bohater przeżył kilka doświadczeń walki z szatanem w ciągu tygodnia (21-27 październik). Wspominając pierwsze doświadczenie, mówi:

stałem, a raczej byłem zawieszony na podświetlonej górze, z której wnętrza biło światło, a ja wewnętrzną siłą przez wyciągnięte ręce starałem się powstrzymać straszną czarną masę, która budziła we mnie grozę. Wiedziałem, że to jest zły duch - szatan.

Drugie opisuje:

jacyśludzie posługiwali się monstrualnym potworem (jakąś układanką, grą komputerową), który zmienił się w młodego i przystojnego mężczyznę, aby móc mordować ludzi. Ja byłem postronnym obserwatorem. Ludzie ci zauważyli, że ich widzę, więc kazali mu mnie zabić, a sami się ukryli. Ten zbliżył się do mnie. Widziałem, jak jego czarne włosy zaczynają rosnąć, a jego czarne przekrwione oczy nabierają jeszcze większej grozy. Wówczas wsadziłem moje palce w jego oczy i poczułem lepkość na palcach i usłyszałem jego jęk. Wtedy obudziłem się przerażony.

Następne wydarzenie rozegrało się na uliczkach średniowiecznego miasta:

szedłem pustą uliczką i poczułem, że ktoś idzie za mną, mimo że nikogo nie widziałem. Doszedłem do bramy miasta, odwróciłem się i zobaczyłem młodego mężczyznę, o którym wiedziałem, że jest szatanem. Złapał mnie za ręce i zaczął się ze mną szamotać. Wiedziałem, że już nie wygram i nie pokonam go. Postanowiłem postawić mu pytania, a on się zgodził. Śmiał się i widziałem, że jest pewny siebie. Zadałem mu pytanie: „Dlaczego mnie wybrałeś?” i kilka innych, których nie pamiętałem. 
Widziałem na jego twarzy, że traci pewność siebie, a po kolejnych pytaniach był zaskoczony. Czułem, że stawałem się silniejszy od niego, i że to ja jestem na pozycji wygranej. Wówczas się obudziłem.

\section{Ogarniająca ciemność i lęk}

Znalazłem się na jakiejś polanie. Przede mną od południowego wschodu widniała góra, a od zachodu nadchodziła przeraźliwie czarna chmura. W niej kotłowało się, wydawała przerażające odgłosy, biła nieustannie piorunami. Burze spotykane na ziemi były tylko igraszką w porównaniu z tym, co mnie otaczało. Wyglądało to jak chmura, która zwiastowała koniec świata. Otoczyła mnie i w mgnieniu oka ogarnęła mnie ciemność. Poczułem, że są to ostatnie chwile mojego życia i za chwilę zostanę osądzony, stanę przed Stwórcą. Przeraźliwie się bałem i wiedziałem, że jeszcze nie jestem gotowy na to, żeby stanąć przed Bogiem i zdać sprawę z całego mojego życia. Krzyczałem, płacząc: „Boże Ojcze dopomóż mi!” i w tej samej chwili obudziłem się.

\section{Przepaść i wysoka fala}

W podobnym nastroju była inna wizja czy sen mojego bohatera. Wspomina:

znalazłem się na bardzo, ale to bardzo wysokim moście. Stałem na jego brzegu, tak, że moje stopy w połowie były poza nim. W dole widziałem wodę, ale jakby to było kilka kilometrów nad ziemią - była tak daleko. Od południowego zachodu nadchodziła szarozielona ogromna fala. Widziałem, jak niszczy wszystko, co napotka na swojej drodze. Ścierała góry, niszczyła miasta, lasy, pola i wszystko, co się tam znajdowało. Zmierzała w moim kierunku i wydawało mi się, że jest wyższa niż most, na którym stoję. Nie bałem się o siebie, ale o ludzi, o całą ludzkość, którą ta ściana wody zabijała. Nie wiedziałem, jak ją powstrzymać. Chciałem coś zrobić, ale nic nie mogłem, patrzyłem, jak zmierza w moim kierunku i niszczy wszystko, co napotyka. W tym momencie obudziłem się.

\section{Tonięcie}

Był lipcowy gorący dzień 2012 r.,

szedłem ulicą i nagle zasłabłem, zabrakło mi powietrza, zrobiło mi się ciemno przed oczami. Zwaliło mnie z nóg na chodnik. W tym samym momencie widziałem, jakby patrząc na siebie z boku, moje ostatnie kroki i w jednym momencie jakbym przeszedł przez szybę na drugą stronę, do innej rzeczywistości. Z tego świata, jakbym 
wpadł w inny, a była to jakby woda, zacząłem tonąć, ale spadałem plecami do dołu. Przed sobą widziałem światło, a pode mną był mrok. Zacząłem się bać, bo tego światła było coraz mniej wokół mnie, a stawało się wyrazistym punktem w oddali. Wiedziałem, że opuściłem ciało, które leży na chodniku. Ktoś mnie zawołał po imieniu i wówczas ocknąłem się, widząc nad sobą grupę ludzi, którzy zastanawiali się, co się ze mną stało i jak mi pomóc. Jednak nie było tam nikogo, kto znałby moje imię.

\section{Ogród, kwiaty na łące}

W czerwcu 2014 r. mój bohater znalazł się w ogrodzie:

był to cudowny ogród pełen różnego rodzaju drzew. Wszystkie z nich kwitły różnego rodzaju kwiatami, które przybierały rożne, bardzo żywe kolory. Takich nie spotkałem nigdy na ziemi. Z drzew dochodziły mnie śpiewy różnych ptaków. $\mathrm{Z}$ tego przecudownego sadu wyszedłem na łąkę pełną różnych kwiatów mieniącą się całą paletą kolorów. Wszystkie kolory były żywe, a ja odczuwałem wyborne, świetne zapachy, których nie jestem w stanie opisać. Czułem się tam wspaniale, byłem spokojny, radosny, poczułem, że wokół mnie jest ktoś, kto otacza mnie bezgraniczną i bezwarunkową miłością oraz zaufaniem. Czułem się bardzo bezpieczny, radosny, szczęśliwy. Mój spokój zburzyła świadomość, że nie ma tu mojej rodziny, najbliższych, przyjaciół i znajomych, zapragnąłem żeby ich zaprosić i w tej samej chwili ocknąłem się.

\section{Niebieskie Jeruzalem}

Był kwiecień 2015 r., gdy mój bohater miał następując przeżycie podczas nocy:

W pewnej chwili znalazłem się na łące, która była oświetlona punktowo, jakby słońcem albo raczej reflektorem z bardzo mocnym ciepłym światłem. Nie stałem w centrum tego koła światła, ale na jego południowym obrzeżu. Przez łąkę przebiegała ledwo widoczna ścieżka. Wokół panowała czarna noc, niebo i wszystko obok było przeraźliwie czarne, nic nie widziałem poza tym oświetlonym fragmentem łąki w kształcie koła. Ta ścieżka wchodziła w ten mrok, czerń. Wiedziałem jednak, że muszę iść tą ścieżką w kierunku północnym, dotrzeć do domu. Ruszyłem przed siebie. Kiedy wszedłem w tę czerń, ona zniknęła, a ja znalazłem się na wąskiej drodze schodzącej w dół, którą z lewej strony ograniczała wysoka skała, a z prawej była przepaść. Ścieżka i całe otoczenie było w brawach brązowych i pomarańczowych, nadając miejscu uczucia bezpieczeństwa i spokoju. Jakby na przeciwległym zboczu góry ujrzałem miasto, które było oświetlone pięknym, ciepłym światłem. Widziałem 
białe mury obronne miasta z ich bramami, a w nim domy, wieże kościołów, kopuły. Wszystko było cudownie kolorowe. Błyszczały tam wszystkie kolory świata, ale nie były takie, jakie widuję na co dzień. Były jakby podświetlone, oświetlone a zarazem świecące własnym blaskiem, bardzo żywe, po prostu inne, wręcz magiczne, nierzeczywiste. Niebo poza nim było czarne, nie było na nim gwiazd czy księżyca ${ }^{11}$. Miasto wyglądało przepięknie i cieszyłem się, że zmierzam do niego. Przede mną szły dwie osoby, gdzieś w odległości kilkuset metrów, a za mną jedna. Nie wiem, czy to byli mężczyźni, czy kobiety. Widziałem tylko sylwetki osób. Nie mogłem rozróżnić ich płci. Wiem, że bardzo się zdziwiłem, że tu jest tak pięknie, a tak mało osób chce zobaczyć to cudowne miasto. Chciałem zrobić zdjęcie, aby móc pokazać innym, gdy wrócę, aby ich zachęcić do zobaczenia tego miasta, ale nie miałem aparatu fotograficznego ze sobą. Gdy odwróciłem się do człowieka, który był za mną na ścieżce do miasta, chcąc go zapytać o aparat, wówczas się obudziłem. Długo rozmyślałem nad tym, czego doświadczyłem, nad tym wyjątkowym miastem. Byłem niepocieszony, że nie wszedłem do miasta, żeby go zobaczyć z bliska i długo nie mogłem zasnąć.

\section{Inne przypadki}

Mój bohater w ciągu swojego życia doświadczał jeszcze wiele innych przypadków przechodzenia z życia do śmierci. Czasami, jak to określił, były chwile, gdy coś zaczynało się dopiero dziać, w innych przypadkach były to jakieś obrazy, na przykład: unoszenie się nad ziemią, fruwanie, przebywanie w kilku miejscach jednocześnie, stanie nad przepaścią, pogrążanie się w odmętach morza, przepaści, spadania do czarnej dziury i inne. Zakomunikował, że tego typu przypadków miał wiele w ciągu ponad trzydziestu lat.

Z tego wynika, że te jego doświadczenia niejednokrotnie występowały w ułamkach sekund, a były one spowodowane chorobą serca, która powodowała, że Adrian kilkanaście, a może nawet kilkadziesiąt razy był na granicy życia i śmierci. To zapewne było spowodowane tym na jak długo jego serce przestawało pracować, a on był już „jedną nogą" po drugiej stronie życia. Te kilkunastosekundowe przestoje serca mogły być tego powodem. Serce zatrzymywało się i rozpoczynał się proces umierania. Jednym razem te jego doświadczenia były krótkie a innym dłuższe - tak jak fazy przestoju od kilku do kilkunastu sekund. Najczęściej występowały podczas spoczynku nocnego.

11 Ten opis miasta jest zbieżny z opisem Niebieskiego Jeruzalem w Apokalipsie św. Jana: „I Miastu nie trzeba słońca ni księżyca, by mu świeciły, bo chwała Boga je oświetliła, a jego lampą - Baranek" (Ap 21,23). 
Na gruncie socjologii medycyny od dawna mówi się (Anselm Strauss ${ }^{12}$, Michael Bury ${ }^{13}$, Michał Skrzypek ${ }^{14}$ ) o chorobie jako sytuacji krytycznej lub też jako formie zakłócenia biograficznego (biographical disruption). Według Burego pod wpływem choroby przewlekłej ulegają załamaniu zachowania i założenia uważane za oczywiste, ale także ujawniają się głębsze załamania w zakresie systemów objaśniających stan, w jakim znajduje się przewlekle chory. Skutkiem tego jest zarówno konieczność ponownej rekonstrukcji osobistej biografii, jak i indywidualnej koncepcji siebie jako osoby ${ }^{15}$.

Adrian miał duże trudności z opowiadaniem swoich przeżyć, bo jak twierdził: „żadne słowa nie oddadzą tego, co przeżywałem, co odczuwałem i co widziałem. To była bezgraniczna ufność i miłość, bezgraniczy spokój, przerażający strach i lęk, ale to były ciepłe kolory oraz ciepłe i przyjazne światło. Po prostu nie da się tego ująć słowami". Te wydarzenia były przesycone barwami, energią i życiem. Odbierał zapachy i słyszał to co się wokół niego działo. Były to wydarzenia z pogranicza śmierci i tego, co po niej następuje.

Można tu mówić o refleksji w procesie całożyciowego uczenia się z biografii ${ }^{16}$, gdyż wszystkie te wydarzenia były związane z trybem życia mojego bohatera i bezwzględnie podlegają badaniom biograficznym ${ }^{17}$. W czasie matury był w trakcie poszukiwa-

12 A. L. Strauss, B. G. Gllaser i in., Chronic Illness and the Quality of Life, Saint Luis 1975.

13 M. Bury, Chronic Illness as Biographical Disruption, „Sociology of Healt and Illness”, 4 (1982) nr 2, s. $167-182$.

14 M. Skrzypek, Perspektywa chorego w socjologii choroby przewlekłej. Ujęcie teoretyczne, ich ewolucja i recepcja, Lublin 2011.

15 M. Bury, Chronic Illness as Biographical Disruption, s. 169; M. Skrzypek, Perspektywa chorego $w$ socjologii choroby przewlektej, s. 184.

16 E. Dubas, Refleksja autobiograficzna jako aktywność edukacyjna w kontekście catożyciowego uczenia się, w: Wyzwania współczesnej edukacji dorosłych: Aktywność społeczna, kulturalna i oświatowa dorosłych, red. A. Fabiś, S. Kędziora, Mysłowice-Zakopane 2009, s. 41-53; taż, Uczenie się $z$ (własnej) biografii - wprowadzenie, w: Uczenie się $z$ (własnej) biografii, red. E. Dubas, W. Świtalski, Łódź 2011, s. 5-9; taż, Edukacja w andragogicznych badaniach biograficznych - biografia edukacyjna, w: Badanie biografii - źródła, metody, konteksty, red. R. Skrzyniarz, E. Krzewska, W. Zgłobicka-Gierut, Lublin 2014, s. 17-31; taż, Biograficzność w kontekście całożyciowego uczenia się, w: Biografie i uczenie się, red. E. Dubas, J. Stelmaszczyk, Łódź 2015, s. 11-29; taż, Andragogiczne badania biografii - zakresy, trudności, etyka badacza (wybrane aspekty), w: Biografie i uczenie się, red. E. Dubas, J. Stelmaszczyk, Łódź 2015, s. 32-47; J. Golonka-Legut, Uczenie się w perspektywie biograficzności. Perspektywa andragogiczna, „Rocznik Andragogiczny”, 22 (2015) s. 101-118.

17 W. Szulakiewicz, Andragogiki portret zbiorowy w kontekście dyskusji o sensie badań biograficznych, „Rocznik Andragogiczny”, 20 (2013) S. 254-265. 
nia swojej drogi życiowej. Wybór studiów nie był taki prosty. Niedostanie się na studia wiązało się z pójściem do wojska na dwa lata, czego Adrian bardzo nie chciał. Musiał wybierać między tym, co kochał - archeologią a historią, którą lubił; „Na śródziemnomorską [archeologię - R. S.] było tylko 12 miejsc, więc nie miałem szans". Studia, na które się dostał, nie spełniały jego oczekiwań. Późniejsze wydarzenia: walka z szatanem, ciemności i lęki, most i wysoka fala były związane z oddaleniem się od Boga: „powiedziałem mu [Bogu - R. S.], masz wiele spraw na głowie, wojny, głód, cierpienia innych ludzi. Zostaw mnie w spokoju, ja sobie pójdę swoją drogą". Po pewnym czasie Adrian zrozumiał, że Bóg był z nim cały czas, ale tak się od niego oddalił, że musiał ponownie go szukać: „wiedziałem, że czegoś mi brakuje, nie potrafiłem tego nazwać. Czułem jego [Boga - R. S.] obecność, ale szukałem nie ślepej wiary, lecz wiary wynikającej z relacji Bóg - ja. I odlazłem. Choroba i traumatyczne przeżycia uświadomiły mi, że Bóg jest obok mnie bez względu na to, czy tego chcę czy nie. On po prostu jest ze mną". Ewidentnie to widać w jego przeżyciach z ogrodu i niebieskiego Jeruzalem.

Jak można zauważyć, skutkiem choroby Adriana była zmiana trajektorii jego życia czy nawet strategii życiowego postępowania, czy wręcz zmiany systemu wartości. Doszło u niego do pogłębienia własnego „Ja”, odkrycia sensu istnienia i egzystencji dzięki przeżyciom z pogranicza życia i śmierci. Doszło także do zmodyfikowania, przeformułowania, biograficznego dostosowania (biographical accomodation) ${ }^{18}$ wielu wartości w celu uzyskania kontroli nad własną biografią w kontekście jego nowych przeżyćc ${ }^{19}$.

Opisane powyżej wydarzenia wiele nauczyły Adriana i wpłynęły na jego życie. Zrozumiał, że „te małe rzeczy są ważne”, czyli radość dnia codziennego, kochanie bliskich i każdego człowieka z osobna, bez względu na wiek i pozycję społeczną: „zrozumiałem, że nie jest ważne, ile się ma tytułów przed nazwiskiem, jakie dobra się posiada, ale najważniejsze jest to, jakim jest się człowiekiem". Najważniejsza stała się dla niego rodzina, przyjaciele, bliscy, a nie kariera zawodowa: ,jest ważna, ale nie jak dotychczas”, awanse, zaszczyty. Uważa on, że: „nawet po śmierci trwa proces uczenia się", a „najistotniejsze są miłość i wiedza, jaką się zdobywa, będąc po drugiej stronie życia". Adrian nie wspominał o zdobywaniu wiedzy, ale te przeżycia niosły ze sobą nową wiedzą, której on był

18 J. Corbin, A. L. Strauss, Accompaniments of Chronic Illness: Changes In Body, Self, Biography, and Biographical Time, w: Researche in the Sociology of Health Care. A Reesearch Annual. The Experience and Management of Chronic Illness, red. J. A. Roth, P. Conrad, Greenich-London 1987, s. 251; M. Skrzypek, Perspektywa chorego w socjologii choroby przewlekłej, s. 234.

19 K. Mariańczyk, Choroba nowotworowa jako element kształtujący biografię, w: Wzory i wzorce osobowe w biografistyce pedagogicznej, red. R. Skrzyniarz, M. Gajderowicz, T. Wach, Lublin 2013, s. 291-302. 
sygnatariuszem. Nie oczekuje aplauzu od innych, a wręcz przeciwnie: „peszy mnie chwalenie, gdy ktoś mi pochlebia, dowartościowuje mnie, bo to jest ludzkie i dzisiaj jest, a jutro już tego nie ma”. Najważniejsza jest według niego ufność w miłość Boga do niego. Najważniejszym dla niego jest to, jak Bóg go oceni, a nie inni ludzie. To nie jest celem jego zabiegów, żeby po ludzku być uwielbianym.

Przeżycia Adriana niosą ze sobą potrójny wymiar edukacyjny. 1) życie nie kończy się wraz ze śmiercią; 2) Bóg istnieje, jest to Bóg Ojciec, miłujący i miłosierny; 3) nastąpiła zmiana w jego życiu, postawił akcenty na inne wartości, niż stawiał poprzednio, są to: miłość, szacunek do życia, wszelkiego życia - wobec ludzi i zwierząt: „całe stworzenie jest dziełem Boga”, nadzieja: „świadomość życia po życiu daje mi nadzieję, że po śmierci jest życie”. Uważa, że „ludzie, którzy przeżyli takie doświadczenia, lepiej radzą sobie z przeciwnościami losu, nie boją się śmierci, a na życie patrzą przez inny pryzmat". Szanują każde życie, którego dawcą jest Bóg. Człowiek nie ma prawa go odbierać, gdyż Bóg zapisał w każdym z nas swój kod ${ }^{20}$. Mimo iż Adrian nie przeżył przeglądu całego swojego życia - jak to ma miejsce u wielu osób, które znalazły się na granicy życia i śmierci ${ }^{21}$ - to jednak postanowił zmienić swoje życie, mając świadomość, że ono nie kończy się wraz ze śmiercią.

U Adriana dokonało się przejście „od religii do duchowości”, stał się istotą zarówno poszukującą sensu życia, jak i eksplorującą świata duchowych przeżyćc ${ }^{22}$. Jest to dla niego nowa rzeczywistość. Bohater nie wspominał, że widział Boga czy Jezusa, ale same przeżycia i ich treści odcisnęły w nim tak duże piętno, że jest on przekonany o tym, iż Bóg istnieje: „na samą myśl, że kiedyś go spotkam, odczuwam nieopisaną radość. Wiem, że nikt i nic mi nie może w tym przeszkodzić". Uważam, że do wielu spraw podchodzi z rezerwą i przyjmuje to jako wolę Bożą. Nie udało mu się uzyskać kolejnego stopnia awansu, ale on twierdzi, że „pewnie Bóg tak chciał, a on wie lepiej, co dla mnie jest dobre. Jako dobry Ojciec nie zrobi mi krzywdy". Widać w Adrianie wiarę, nie dewocyjność, ale wiarę w Opatrzność. Twierdzi, że tam „czas i odległość, jakie znamy, nie istnieją”.

20 G. Braden, Kod Boga. Boski pienwiastek w każdym z nas, Białystok 2012.

21 R. A. Moody, Życie po życiu, s. 64-71.

22 A. Kasperek, Wolność spod znaku undergrandu. Duchowość (po)nowoczesna w perspektywie hermeneutyki kultury i socjologii religii, Kraków 2012, s. 101; M. Rembierz, Tropy transcendencji... Współczesne myślenie religijne wobec pluralizmu światopoglądowego i relacji międzykulturowych, „Świat i Słowo. Filologia - Nauki Społeczne - Filozofia - Teologia”, 2 (23) 2014, s. 26-27; J. Semków, Duchowy wymiar dorosłości antidotum na lęki egzystencjalne, „Edukacja Dorosłych", 1 (72) 2015, s. 69-79. 
To zostało już potwierdzone przez fizyków kwantowych, że czas i przestrzeń, jakie znamy na ziemi, nie są takie same. Robert Lanza wręcz twierdzi, że teoria kwantowa dowodzi, iż świadomość w momencie śmierci przenosi się do innego wszechświata. Po prostu świadomość istnieje poza ograniczeniami narzuconymi przez czas i przestrzeñ ${ }^{23}$. Tak to określa nauka, zaś dla wierzących świadomość, że życie zmienia się, ale się nie kończy. Jest to tylko dowód naukowy na słuszność ich wiary w życie po życiu, gdzie życie po śmierci jest tylko innym stanem świadomości człowieka.

Streszczenie: $\mathrm{W}$ artykule zostały ukazane i przeanalizowane przeżycia bohatera wywiadu ukazujące jego przeżycia związane z pogranicza życia i śmierci. Twierdzi on, że miał ich w swoim życiu wiele, jednak zostało omówionych tylko dziesięć obejmujących ponad trzydzieści lat jego życia: 1) ciemność i światło; 2) wyjście z ciała i spacer; 3) kule ognia i planety; 4) widok z kosmosu; 5) walka z szatanem; 6) ogarniająca ciemność i lęk; 7) przepaść i wysoka fala; 8) tonięcie; 9) ogród, kwiaty na łące; 10) niebieskie Jeruzalem. Wszystkie te przeżycia były również związanych z jego postawami, sposobem życia, wiarą w Boga i jej negacją.

Relacje zawierają również wartości pedagogiczne, ukazujące związek życia ludzkiego z dwoma istotnymi elementami tego doświadczenia, w którym są miłość wobec ludzi i zdobyta wiedza. Bohater po tych przeżyciach z pogranicza życia i śmierci zrozumiał, że: 1) życie nie kończy się wraz ze śmiercią; 2) Bóg istniej i jest on Ojcem miłosiernym; 3) najważniejsza jest miłość i szacunek wobec wszelkiego życia.

Słowa kluczowe: biografia, wywiad narracyjny, choroba przewlekła, doświadczenie śmierci

\section{Bibliografia}

Braden G., Kod Boga. Boski pierwiastek w każdym z nas, Białystok 2012.

Brown M. H., Po drugiej stronie, przeł. M. H. Kotlarz, Gdańsk 2010, wyd. 2: przeł. M. Szerocki, Kraków 2013.

Browne M. T., Życie po śmierci, przeł. M. Kowalska, Warszawa 1997.

23 L. Randall, Ukryte wymiary wszechświata, przeł. B. Bieniok i E. L. Łokas, Warszawa 2012; taż, Pukając do nieba bram. Jak fizyka pomaga zrozumieć wszechświat, Warszawa 2013; M. Heller, Bóg i geometria, gdy przestrzeń była bogiem, Kraków 2015; M. Kozłowski, Czas i nieskończoność. Rozważania o ludzkim trwaniu dla wierzacych w Boga, Gdynia 2015; R. Skrzyniarz, Biografia ruchoma, zmienna, niestabilna - przyszłość zmienia się w zależności od tego, jak patrzymy na przeszłość, w: Badania biografii - źródła, metody, konteksty, red. R. Skrzyniarz, E. Krzewska, W. Zgłobicka-Gierut, Lublin 2014, s. 85-95; R. Lanza, Beyond Biocentrism: Rethinking Time, Space, Consciousness, and the Illusion of Death, Dallas 2016. 
Bury M., Chronic Illness as Biographical Disruption, „Sociology of Healt and Illness”, 4 (1982) nr 2, s. 167-182.

Corbin J., A. L. Strauss, Accompaniments of Chronic Illness: Changes In Body, Self, Biography, and Biographical Time, w: Researche in the Sociology of Health Care. A Reesearch Annual. The Experience and Management of Chronic Illness, red. J. A. Roth, P. Conrad, Greenich-London 1987, s. 249-281.

Dubas E., Andragogiczne badania biografii - zakresy, trudności, etyka badacza (wybrane aspekty), w: Biografie i uczenie się, red. E. Dubas, J. Stelmaszczyk, Łódź 2015, s. 32-47.

Dubas E., Biograficzność w kontekście całożyciowego uczenia się, w: Biografie i uczenie się, red. E. Dubas, J. Stelmaszczyk, Łódź 2015, s. 11-29.

Dubas E., Edukacja w andragogicznych badaniach biograficznych - biografia edukacyjna, w: Badanie biografii - źródła, metody, konteksty, red. R. Skrzyniarz, E. Krzewska, W. Zgłobicka-Gierut, Lublin 2014, s. 17-31.

Dubas E., Refleksja autobiograficzna jako aktywność edukacyjna w kontekście całożyciowego uczenia się, w: Wyzwania współczesnej edukacji dorosłych: Aktywność społeczna, kulturalna i oświatowa dorosłych, red. A. Fabiś, S. Kędziora, Mysłowice-Zakopane 2009, s. 41-53.

Dubas E., Uczenie się z (własnej) biografii - wprowadzenie, w: Uczenie się z (własnej) biografii, red. E. Dubas, W. Świtalski, Łódź 2011, s. 5-9.

Golonka-Legut J., Uczenie się w perspektywie biograficzności. Perspektywa andragogiczna, „Rocznik Andragogiczny”, 22 (2015) s. 101-118.

Heller M., Bóg i geometria, gdy przestrzeń była bogiem, Kraków 2015.

Homer, Odyseja, tłum. L. Siemieński, Warszawa 2000.

Jakoby B., Drogi nieśmiertelności. Nowa wiedza o doświadczeniach z pogranicza życia i śmierci, przeł. T. A. Czarnawski, Warszawa 2012.

Kasperek A., Wolność spod znaku undergrandu. Duchowość (po)nowoczesna w perspektywie hermeneutyki kultury i socjologii religii, Kraków 2012.

Kozłowski M., Czas i nieskończoność. Rozważania o ludzkim trwaniu dla wierzących w Boga, Gdynia 2015.

Kübler-Ross E., Koło życia. Rozważania o życiu i umieraniu, tłum. J. Korpanty, Warszawa 2010.

Lanza R., Beyond Biocentrism: Rethinking Time, Space, Consciousness, and the Illusion of Death, Dallas 2016.

Long J., P. Perry, Evidence of the Afterlife. The Science of Near-Death Experiences, New York 210. Mariańczyk K., Choroba nowotworowa jako element kształtujący biografię, w: Wzory i wzorce osobowe w biografistyce pedagogicznej, red. R. Skrzyniarz, M. Gajderowicz, T. Wach, Lublin 2013, s. 291-302.

Moody R. A., Życie po życiu, przeł. I. Doleżal-Nowicka, Warszawa 1979, 2008.

Randall L., Pukając do nieba bram. Jak fizyka pomaga zrozumieć wszechświat, Warszawa 2013.

Randall L., Ukryte wymiary wszechświata, przeł. B. Bieniok i E. L. Łokas, Warszawa 2012.

Rembierz M., Tropy transcendencji... Współczesne myślenie religijne wobec pluralizmu światopoglądowego i relacji międzykulturowych, „Świat i Słowo. Filologia - Nauki Społeczne - Filozofia - Teologia", 2 (2014) s. 17-50. 
Rymuszko M., Polskie życie po życiu. Relacje ludzi uratowanych ze stanu śmierci klinicznej, Warszawa 2004.

Semków J., Duchowy wymiar dorosłości antidotum na lęki egzystencjalne, „Edukacja Dorosłych", 1 (2015) s. 69-79.

Skrzyniarz R., Biografia ruchoma, zmienna, niestabilna - przyszłość zmienia się w zależności od tego, jak patrzymy na przeszłość, w: Badania biografii - źródła, metody, konteksty, red. R. Skrzyniarz, E. Krzewska, W. Zgłobicka-Gierut, Lublin 2014, s. 85-95.

Skrzypek M., Perspektywa chorego w socjologii choroby przewlekłej. Ujęcie teoretyczne, ich ewolucja i recepcja, Lublin 2011.

Stone R., Życie po śmierci, przeł. M. Korusiewicz, Katowice 1999.

Strauss A. L., B. G. Gllaser i inni, Chronic Illness and the Quality of Life, Saint Luis 1975.

Szulakiewicz W., Andragogiki portret zbiorowy w kontekście dyskusji o sensie badań biograficznych, „Rocznik Andragogiczny”, 20 (2013) s. 254-265.

Wergiliusz, Eneida. Epopeja w dwunastu księgach, tłum. i oprac. I. Wieniewski, Kraków 1978.

Wilson I., Życie po śmierci, przeł. M. Glińska, Warszawa 1998. 